\title{
THE EFFECT OF WORK-LIFE BALANCE ON INTENTION TO STAY MEDIATED BY PSYCHOLOGICAL EMPOWERMENT
}

\author{
Intan Nur Sofia \\ Faculty of Islamic Economics and Business, IAIN Surakarta, Indonesia \\ intannursofia160@gmail.com \\ Walyoto \\ Faculty of Islamic Economics and Business, IAIN Surakarta, Indonesia \\ walyoto.colomadu@yahoo.com
}

\begin{tabular}{|c|c|}
\hline Article Info & Abstract \\
\hline $\begin{array}{l}\text { Article History } \\
\text { Received: } \\
22 \text { April } 2021\end{array}$ & $\begin{array}{l}\text { This study was intended to analyze the effect of supervisor } \\
\text { support and job autonomy on the intention to stay. This study } \\
\text { also examines the effect of psychological empowerment on the } \\
\text { intention to stay. The sampling method used was non- } \\
\text { probability sampling with the samples of female nurses in all } \\
\text { hospitals in the Sragen Regency. The analysis used the } \\
\text { Structural Equation Model (SEM) Software using AMOS } 22 \text { to } \\
\text { test and estimate the causal relationship of a combination of } \\
\text { statistical data and qualitative causal assumption data. The } \\
\text { results of the SEM analysis of } 187 \text { respondents showed that } \\
\text { there was a significant effect of psychological empowerment on } \\
\text { supervisor support and intention to stay. However, } \\
\text { psychological empowerment cannot bridge the effect of job } \\
\text { autonomy and the intention to stay. Furthermore, this study } \\
\text { also shows that variable of the supervisor support is the most } \\
\text { significant variable in affecting psychological empowerment } \\
\text { compared tojob autonomy. Thus, the beststrategy in increasing } \\
\text { the desire of employees to stay in the company is to increase } \\
\text { supervisor support and psychological empowerment. }\end{array}$ \\
\hline & $\begin{array}{l}\text { Keywords: Supervisor Support, Job Autonomy, Psychological } \\
\text { Empowerment, Intention to Stay }\end{array}$ \\
\hline
\end{tabular}

\section{INTRODUCTION}

Nowadays, the study on employee empowerment is one gains attention preparing for competition. Employee empowerment provides opportunities for employees to have a career by mobilizing all experience, knowledge, and motivation to produce maximum performance. Hunjra (2011) states that empowerment can increase responsibility. Motivation in work increases satisfaction, service quality, loyalty, and productivity to reduce turnover. Hence, every organization should pay attention to the well-being of employees through psychological empowerment. 
Smithikrai \& Phetkham (2019) added that if individuals are psychologically empowered, they are internally motivated to do a good job.

Danastri (2018) elaborates on several factors affecting employee well-being including genetic factors, personality, subjective satisfaction, and social relationships. Social relations have a strong attachment to the quality of life since it is one of the domains to create a positive quality of life. For employees, this quality of life can be improved by achieving a work-life balance. Iswardhani., et All (2019) argues that work-life balance allows employees to better manage their work and non-work activities. In line with Akbar et all., (2019), organizations with good autonomy can increase psychological empowerment among employees. According to Nesheim et al., (2017), organizations with high autonomy and freedom will create better service quality and encourage employees to develop psychological empowerment. Work autonomy and supervisor support are important part of the concept of employee's work-life balance. Work-life balance is very interesting to study Chiang \& Chang 2012), Tourangeau (2014); Ghosh (2013); (Smithikrai \& Phetkham, 2019). Especially work-life balance for female workers, it is interesting to study since the number of working women has increased (Raffi, 2020). In addition, women tend to experience multiple role conflicts. Women traditionally have more conflicts due to the number of roles they perform. Married women have their own challenges compared to unmarried women (Adame et al., 2016; Wulandari, 2020).

Supervisor support plays an important role in work-life balance. Ramdhani \& Ratnasawitri (2017) added that supervisor support impacts commitment, job satisfaction, positive mood, work involvement, and desire to stay. During the Covid-19 pandemic, hospitals have a vital role in preventing the transmission of the Covid-19 virus. Thus, it is very important to involve nurses as the front line in serving public health for Covid-19 spread prevention. The reason individuals keep working in an organization is the work-life balance (Chiang \& Chang 2012). One of the causes for low loyalty is the lack of work-life balance of nurses. This study examined some of the findings of previous studies which show that work-life balance can increase the desire of employees to stay in the company Tourangeau (2014); Ghosh (2013); (Smithikrai \& Phetkham, 2019). Some studies show that psychological empowerment can increase the intention to stay (Ghosh et al., 2013); (Aboobaker et al., 2019); (Dian Maulida, 2017); (Rostiana, 2018); (Bester et all., 2012); (Presbitero \& Teng-calleja, 2019)

\section{LITERATURE REVIEW AND HYPOTHESIS DEVELOPMENT}

\section{The Effect of Work Autonomy and Supervisor Support on Psychological Empowerment}

The theoretical framework of this study integrates the theory from Maslach and Leiter (1997 in (Greenhaus et al., 2003), theory of the work-life balance Leiter \& Maslach, (2003) 
explaining that the suitability of an employee with his work in six areas of work-life, including managed workload, control, reward, fairness, sense of community, and harmony between personal and organizational values. Doble \& Supriya (2010) have observed several issues regarding childrearing, the need to balance multiple roles which have consequences on health and family relationships.

Previous researches have discussed work-life balance as a means to increase intention to stay. Important dimensions of work-life balance are job autonomy and supervisor support (Suifan et al., 2016). Rehman \& Roomi (2012) added that work autonomy has an important role in achieving a balance of life between work and family. Handayani et all., (2018) state that work autonomy allows employees to have the freedom and flexibility to manage workloads to minimize pressure, fatigue and conflict.

Baloyi et al., (2014) state that supervisors play an important role in meeting the needs of employees by empowering them through work-life balance. Psychological empowerment is an external aspect to be able to succeed in an organization (Hunjra, 2011). Supervisor support and psychological empowerment are very important in fulfilling work-life balance. This is because supervisor support has affect employees who are directly engaged in individual work. Ramdhani \& Ratnasawitri (2017) added that supervisor support impacts commitment, job satisfaction, positive mood, work engagement, and desire to stay.

A company with autonomy, freedom, and a conducive work climate increases psychological empowerment. It is in line with empirical studies Akbar et al., (2019), Wang \& Lee, (2011) showing that work autonomy has a significant effect on psychological empowerment. This is because strong autonomy increases the opportunity for employees to interpret their duties, encourages intrinsic motivation, and increases work comfort. In a study conducted by Smithikrai \& Phetkham (2019), it is assumed that work-life balance, psychological empowerment, and job satisfaction are critical situational factors that can encourage intention to stay. This is also supported by Wulandari (2020) that there are many supporting factors including job satisfaction, external role behavior, organizational support, teamwork support, and superior support.

$\mathrm{H}_{1}$ : Job autonomy has a positive effect on psychological empowerment $\mathrm{H}_{2}$ : Supervisor support has a positive effect on psychological empowerment

\section{The Effect of Psychological Empowerment on the Intention to Stay}

Nursanti et all., (2014) state that superior support can create psychological empowerment in employees. Superior support is the feeling obtained when superiors care about their wellbeing, appreciate their contributions, and support their work (Amalia \& Handoyo, 2018). A study conducted by Bester et al., (2012) shows that providing employee empowerment can produce 
positive experiences related to work, which can increase employee satisfaction and reduce turnover rates. Nimitha et all., (2018) added that there is psychological empowerment in an organization in creating positive emotions in employees. With a higher level of wellbeing in the workplace, it will be reflected in a better intention to stay with the organization. Other studies that support this statement where there is a positive relationship between Psychological empowerment and intention to stay (Dewettinck \& Van Ameijde, 2011; Rostiana, 2018)

$\mathrm{H}_{3}$ : Psychological empowerment has a positive effect on the intention to stay

\section{The effect of Job Autonomy and Supervisor Support on the Intention to Stay}

Sheemun et all., (2013) consider that work autonomy is a form of freedom and independence as well as organizational support for employees. Based on research conducted by Tang et al., (2016) autonomy serves as an incentive for employees who can increase the desire to stay by showing a high level of involvement in their work. Furthermore, employees with supervisor support will be motivated and have a great concern for the organization. The supervisor support increases the desire of employees to stay in the organization (Liu et all., 2016). Supervisor support can affect the intention to stay (Ramdhani et all., 2017). A study carried out by Wulandari, (2020) adds that supervisor support has the highest impact in developing and increasing satisfaction and the desire to stay in the organization.

$\mathrm{H}_{4}$ : Job autonomy has a positive effect on the intention to stay

$\mathrm{H}_{5}$ : Supervisor support has a positive effect on the intention to stay

\section{METHOD}

\section{Population, Sample, and Sampling Technique}

The population in this study were all female nurses in Sragen Regency. Determination of the number of samples in this study refers to Hair et al., (2010) regarding the assumption of sample adequacy in a structural equation model, which is 100-200 samples. There are two methods used in questionnaire distribution. They are directly given to the respondents and through the online Google Form. There were 194 Google Form questionnaires filled out and 27 direct questionnaires. A total of 221 questionnaires were collected. However, after selecting the completeness of the respondent's answers, the data deemed worthy of meeting the criteria for analysis were 187 respondents.

In this study, a non-probability sampling technique of purposive sampling was carried out. The researcher considers several factors in selecting members of the population that are considered appropriate in providing the required information. The requirements for sampling include female 
114 Sofia, I. N. \& Walyoto, The Effect of Work-Life Balance on Intention to Stay Mediated by...

nurses, nurses who are married/family breadwinners, and nurses with work experience for at least 2 years.

\section{Data Source}

The source of data used in this study was primary data using a questionnaire. The questionnaire used in this study was a closed-ended questionnaire. The researcher has provided answer choices and then the respondent. This study used an interval scale instrument with the agree-disagree scale technique (Ferdinand, 2014).

\section{Data Analysis}

The data analysis used in this research is quantitative analysis. This study used Structural Equation Modeling (SEM) analysis with AMOS 22 software.

\section{RESULTS}

\section{Descriptive Analysis}

Table 1. Cross-tabulation of Respondent's Age and Education

\begin{tabular}{|c|c|c|c|c|c|}
\hline \multirow{2}{*}{\multicolumn{3}{|c|}{ Age }} & \multicolumn{2}{|c|}{ Level of Education } & \multirow{3}{*}{$\begin{array}{l}\text { Total } \\
87 \\
\end{array}$} \\
\hline & & & \multirow{2}{*}{$\begin{array}{r}\text { Diploma } \\
74 \\
\end{array}$} & \multirow{2}{*}{$\begin{array}{l}\begin{array}{l}\text { Bachelor's } \\
\text { Degree }\end{array} \\
13 \\
\end{array}$} & \\
\hline 1 & $20-24$ Years Old & Person & & & \\
\hline 1 & $20-24$ iears uid & $\%$ & $39.6 \%$ & $7.0 \%$ & $46.5 \%$ \\
\hline \multirow{2}{*}{2} & \multirow{2}{*}{ 25-29 Years Old } & Person & 22 & 11 & 33 \\
\hline & & $\%$ & $11.8 \%$ & $5.9 \%$ & $17.6 \%$ \\
\hline \multirow{2}{*}{3} & \multirow{2}{*}{ 30-34 Years Old } & Person & 24 & 15 & 39 \\
\hline & & $\%$ & $12.8 \%$ & $8.0 \%$ & $20.9 \%$ \\
\hline \multirow{2}{*}{5} & \multirow{2}{*}{ >35 Years Old } & Person & 16 & 12 & 28 \\
\hline & & $\%$ & $8.6 \%$ & $6.4 \%$ & $15.0 \%$ \\
\hline & \multirow{2}{*}{ Total } & Person & 136 & 51 & 187 \\
\hline & & $\%$ & $72.7 \%$ & $27.3 \%$ & $100.0 \%$ \\
\hline
\end{tabular}

Source: Primary data processing (2021)

Table 1 shows that the number of female nurses who took Diploma education was $72.7 \%$. Meanwhile, nurses who took Bachelor education was $27.3 \%$. The data shows that the age of respondents who are at the peak of nurse work productivity is in the age range of 20-25 years by $46.5 \%$. The nurses in this study have the potential to develop their abilities.

Table 2. Cross Tabulation of Age and Marital Status

\begin{tabular}{|c|c|c|c|c|c|c|}
\hline \multirow{2}{*}{\multicolumn{3}{|c|}{$\begin{array}{l}\text { Age } \\
\end{array}$}} & \multirow{2}{*}{\multicolumn{3}{|c|}{ Marital Status }} & \multirow{3}{*}{$\begin{array}{r}\text { Total } \\
\\
87 \\
\end{array}$} \\
\hline & & & & & & \\
\hline 1 & 20-24 Years Old & Person & $\begin{array}{r}\text { Married } \\
87 \\
\end{array}$ & $\begin{array}{r}\text { Divorced } \\
0\end{array}$ & $\begin{array}{r}\begin{array}{c}\text { Death } \\
\text { Divorce }\end{array} \\
0\end{array}$ & \\
\hline & & $\%$ & $46.5 \%$ & $0.0 \%$ & $0.0 \%$ & $46,5 \%$ \\
\hline \multirow[t]{3}{*}{2} & \multirow[t]{3}{*}{ 26-30 Years Old } & Person & 31 & 2 & 0 & 33 \\
\hline & & $\%$ & $16.6 \%$ & $1.1 \%$ & $0.0 \%$ & $17,6 \%$ \\
\hline & & Person & 35 & 3 & 1 & 39 \\
\hline
\end{tabular}




\begin{tabular}{|c|c|c|c|c|c|c|}
\hline 3 & 30-34 Years Old & $\%$ & $18.7 \%$ & $1.6 \%$ & $0.5 \%$ & $20.9 \%$ \\
\hline \multirow[t]{2}{*}{5} & \multirow[t]{2}{*}{$>35$ Years Old } & Person & 21 & 5 & 2 & 28 \\
\hline & & $\%$ & $11.2 \%$ & $2.7 \%$ & $1.1 \%$ & $15,0 \%$ \\
\hline \multirow{2}{*}{\multicolumn{2}{|c|}{ Total }} & Person & 153 & 28 & 7 & 187 \\
\hline & & $\%$ & $93,0 \%$ & $5.3 \%$ & $1.6 \%$ & $100.0 \%$ \\
\hline
\end{tabular}

Source: Primary data processing (2021)

Cross tabulation on age and marital status is shown in Table 2. It shows that respondents aged 20-24 are married by $46.5 \%$, respondents aged 26-30 who are married are $16.6 \%$, respondents aged 30-34 who are married are 18.7\%, and respondents aged $>35$ who are married are $11.2 \%$. Overall, respondents aged 20-24 years dominate respondents who are married.

Table. 3 Cross Tabulation of Marital Status and Respondent's Income

\begin{tabular}{|c|c|c|c|c|c|}
\hline \multirow{2}{*}{ No. } & \multirow{2}{*}{ Marital Status } & Married & Divorced & $\begin{array}{c}\text { Death } \\
\text { Divorce }\end{array}$ & \multirow{2}{*}{ Total } \\
\cline { 3 - 6 } & & & & 0 & 66 \\
\hline \multirow{2}{*}{1} & IDR 1.000.000 & 66 & 0 & $0.0 \%$ & $23.9 \%$ \\
\cline { 2 - 6 } & $\%$ & $35.3 \%$ & $0.0 \%$ & 1 & 102 \\
\hline \multirow{3}{*}{2} & $\begin{array}{c}\text { IDR 1000.0000- } \\
\text { IDR 5.000.000 }\end{array}$ & 92 & 9 & & \\
\cline { 2 - 6 } & $\%$ & $49.2 \%$ & $4.8 \%$ & $0.5 \%$ & $54,5 \%$ \\
\hline \multirow{2}{*}{3} & IDR > Rp.5.000.000 & 16 & 1 & 2 & 19 \\
\cline { 2 - 6 } & $\%$ & $8.6 \%$ & $0.5 \%$ & 1.1 & $10,2 \%$ \\
\hline \multirow{3}{*}{} & Total $\%$ & 174 & 10 & 3 & 187 \\
\cline { 2 - 6 } & & $93,0 \%$ & $5.3 \%$ & $1.6 \%$ & $100.0 \%$ \\
\hline
\end{tabular}

Source: Primary data processing (2021)

The cross-tabulation of age and income is presented in Table 3. It shows that there are 174 married respondents, 10 respondents divorced, and 3 respondents who are death divorced. The majority of divorced people have an income of IDR 1000,0000 - IDR 5,000,000, which are 49.2\% and $4.8 \%$ respectively. Meanwhile, the majority of respondents with death divorce had an income of $>$ IDR 5,000,000.

Table 4. Cross-tabulation of Respondent's Education and Income

\begin{tabular}{|c|c|c|c|c|c|c|}
\hline \multirow[t]{2}{*}{ No. } & \multicolumn{2}{|c|}{ Education } & \multicolumn{3}{|c|}{ Income } & \multirow{3}{*}{\begin{tabular}{|c|} 
Total \\
\\
136 \\
\end{tabular}} \\
\hline & & & \multirow{2}{*}{$\begin{array}{c}\text { IDR } 1.000 .000 \\
60\end{array}$} & \multirow{2}{*}{$\begin{array}{c}\text { IDR } 1.000 .0000 \\
- \text { IDR } \\
5.000 .000 \\
73\end{array}$} & \multirow{2}{*}{$\begin{array}{c}>\text { IDR } \\
5.000 .000 \\
\\
3\end{array}$} & \\
\hline \multirow[t]{2}{*}{1} & \multirow[t]{2}{*}{ Diploma } & Person & & & & \\
\hline & & $\%$ & $32,1 \%$ & $39,0 \%$ & $1,6 \%$ & $72,7 \%$ \\
\hline \multirow[t]{2}{*}{2} & \multirow[t]{2}{*}{ Bachelor } & Person & 6 & 29 & 16 & 51 \\
\hline & & $\%$ & $3,2 \%$ & $15,5 \%$ & $8,6 \%$ & $27,3 \%$ \\
\hline & Total & Person & 66 & 102 & 19 & 187 \\
\hline
\end{tabular}




\begin{tabular}{|l|l|l|l|l|l|}
\hline & $\%$ & $35,3 \%$ & $54,5 \%$ & $10,2 \%$ & $100.0 \%$ \\
\hline
\end{tabular}

Source: Primary data processing (2021)

Cross-tabulation of education and income is presented in Table 4. The data shows that respondents with an income of IDR 1,000,000 are dominated by respondents who have a Diploma education of $13.3 \%$. Meanwhile, respondents who have an income of IDR 1.000.0000- IDR 5.000 .000 are dominated by respondents who have a Bachelor education of $28.7 \%$.

\section{Reliability and Validity}

Confirmatory factor analysis shows the average percentage of variance extracted between indicators. It provides an explanation of the summary of convergent indicators. The Average Variance Extracted (AVE) calculated using the loading factor value.

Table 5. Loading Factor, Convergent Validity, Construct Reliability, and Discriminant Validity

\begin{tabular}{|c|c|c|c|c|}
\hline Variable and Indicator & $\begin{array}{l}\text { Std. } \\
\text { Loading } \\
\text { (Lambda } \\
\text { Value) }\end{array}$ & $\begin{array}{c}\text { Convergent } \\
\text { Validity } \\
(\mathrm{AVE}) \geq 0.50\end{array}$ & $\begin{array}{l}\text { Construct } \\
\text { Reliability } \\
\quad \geq 0.70\end{array}$ & $\begin{array}{c}\text { Discriminant } \\
\text { Validity }\end{array}$ \\
\hline $\begin{array}{l}\text { Job autonomy } \\
\text { 1. Position of authority } \\
\text { 2. Independence } \\
\text { 3. Freedom } \\
\text { 4. Independence at work }\end{array}$ & $\begin{array}{l}0.809 \\
0.654 \\
0.631 \\
0.718\end{array}$ & 0.523 & 0.812 & 0.723 \\
\hline $\begin{array}{l}\text { Supervisor support } \\
\text { 1. The trust that supervisors } \\
\text { give to employees } \\
\text { 2. Willing to assist to } \\
\text { employees } \\
\text { 3. Caring for his employees } \\
\text { 4. Provide constructive input } \\
\text { to employees } \\
\text { 5. Provide positive and } \\
\text { accurate information to } \\
\text { employees }\end{array}$ & $\begin{array}{l}0.850 \\
0.840 \\
0.670 \\
0.739 \\
0.843\end{array}$ & 0.647 & 0.917 & 0.804 \\
\hline $\begin{array}{l}\text { Psychological empowerment } \\
\text { 1. Meaning } \\
\text { 2. Perceived Impact } \\
\text { 3. Competence } \\
\text { 4. Self-determination }\end{array}$ & $\begin{array}{l}0.730 \\
0.842 \\
0.677 \\
0.760\end{array}$ & 0.621 & 0.840 & 0.788 \\
\hline
\end{tabular}




\begin{tabular}{|l|l|l|l|l|}
\hline Intention to stay & 0.689 & 0.947 & 0.830 \\
1. Comfort at work & 0.767 & & \\
2. Do not want to look for & 0.820 & & \\
another job & 0.849 & & \\
3. Disinterest in looking for \\
other job vacancies \\
$\begin{array}{l}\text { 4. Awareness that finding } \\
\text { another job is not easy }\end{array}$ & 0.889 & & \\
\hline
\end{tabular}

Source: Primary data processing (2021)

\section{Evaluating the Model Estimation based on the Goodness of Fit Criteria}

Before evaluating the goodness of fit, the structural model assumptions should meet:

1) The normality test was done with univariate and multivariate normality by seeing the CR value on Skewness or kurtosis is expected to be around \pm 2.58 at a significance level of 0.01 . In this study, there were two steps to calculate the first normality by cleaning the outliers and cutting some indicators that have a low loading factor value. It can be seen that the multivariate normality test is 3.127 although it has not been reached at 2.58 but is still tolerable because it is close to 2.58 .

Table 6. Data Normality

\begin{tabular}{|c|c|c|c|c|c|c|}
\hline Variable & Min & Max & skew & c.r. & kurtosis & c.r. \\
\hline JA2 & 5.000 & 10.000 & -.746 & -3.691 & .388 & .960 \\
SS3 & 3.000 & 10.000 & -.700 & -3.466 & .589 & 1.458 \\
JA4 & 4.000 & 10.000 & -1.356 & -6.713 & 1.766 & 4.370 \\
PE2 & 4.000 & 10.000 & -.607 & -3.002 & -.028 & -.070 \\
PE3 & 6.000 & 10.000 & -.046 & -.227 & -.794 & -1.965 \\
PE5 & 4.000 & 10.000 & -.993 & -4.913 & 1.064 & 2.634 \\
IR4 & 3.000 & 10.000 & -1.129 & -5.591 & 1.815 & 4.493 \\
IR2 & 5.000 & 10.000 & -.528 & -2.615 & -.138 & -.341 \\
SS1 & 5.000 & 10.000 & -.580 & -2.872 & .021 & .052 \\
SS2 & 5.000 & 10.000 & -.222 & -1.096 & -.479 & -1.184 \\
SS5 & 4.000 & 10.000 & -.573 & -2.835 & .535 & 1.325 \\
JA3 & 6.000 & 10.000 & -.244 & -1.208 & -.709 & -1.754 \\
\hline \multicolumn{7}{|c|}{ Multivariate } \\
\hline
\end{tabular}

Source: Primary data processing (2021)

2) Outlier Evaluation on Mahalanobis

Mahalanobis distance X2(12,0.001) = 32,909 based on the Chi-squares value on the degree of freedom of 12 indicators in this study at a significance level of 0.001.12. The value of Mahalanobis distance X2 $(12,0.001)=32,909$. The numbers in the Mahalanobis distance squared are all below 32,909. Thus, they are free from multivariate outlier data.

Table 7. Mahalanobis Distance Value 


\begin{tabular}{|r|r|r|r|}
\hline $\begin{array}{c}\text { Observation } \\
\text { number }\end{array}$ & Mahalanobis d-squared & $\mathrm{p} 1$ & $\mathrm{p} 2$ \\
\hline 14 & 27.394 & .007 & .263 \\
25 & 25.307 & .013 & .316 \\
136 & 24.868 & .015 & .194 \\
41 & 24.217 & .019 & .149 \\
48 & 22.232 & .035 & .410 \\
46 & 22.004 & .037 & .314 \\
47 & 20.940 & .051 & .483 \\
52 & 20.704 & .055 & .417 \\
127 & 20.645 & .056 & .306 \\
$\ldots$ & $\ldots$ & $\ldots$ & $\ldots$ \\
$\ldots$ & $\ldots$ & $\ldots$ & $\ldots$ \\
\hline$\ldots$ & $\ldots .234$ & .683 & .566 \\
124 & & & $\ldots$ \\
\hline
\end{tabular}

3) Evaluation of multicollinearity and singularity on the determinant of the sample covariance matrix

It is expected that the Determinant of Sample Covariance Matrix stays away from zero and is even better if $>1$. Data processing used AMOS 22 software produces a determinant value of the sample covariance matrix of 0.287 .

4) Evaluation of goodness of fit $(\mathrm{GoF})$ criteria

Table 8. The Goodness of Fit of Research Model

\begin{tabular}{|l|c|c|c|}
\hline \multicolumn{1}{|c|}{ Goodness of Fit } & Cut off Value & $\begin{array}{c}\text { Hasil } \\
\text { Pengujian }\end{array}$ & Keterangan \\
\hline $\mathrm{X}^{2}-$ Chi-square & 58.124 & 54.849 & Fit \\
\hline Probability & $\geq 0.05$ & 0.088 & Fit \\
\hline DF & & 42 & \\
\hline GFI & $\geq 0.90$ & 0.941 & Fit \\
\hline AGFI & $\geq 0.90$ & 0.891 & Fit \\
\hline RMSEA & $0.03-0.08$ & 0.046 & Fit \\
\hline CMIN/DF & $\leq 2.00$ & 1.306 & Fit \\
\hline NFI & $\geq 0.90$ & 0.945 & Fit \\
\hline CFI & $\geq 0.95$ & 0.986 & Fit \\
\hline TLI & $\geq 0.95$ & 0.978 & Fit \\
\hline
\end{tabular}

Table. 9. Standardized Regression Weights

\begin{tabular}{|l|l|l|l|l|l|}
\hline & Estimate & S.E & C.R & P & Description \\
\hline
\end{tabular}




\begin{tabular}{|c|c|c|c|c|c|}
\hline Job autonomy $\rightarrow$ Psychology & .052 & .282 & .183 & .854 & Rejected \\
\hline $\begin{array}{l}\text { empowerment } \\
\text { Supervisor support } \rightarrow \text { Psychology } \\
\text { empowerment }\end{array}$ & .757 & .190 & 3.979 & $* * *$ & Accepted \\
\hline $\begin{array}{l}\text { Psychology empowerment } \rightarrow \\
\text { Intention to stay }\end{array}$ & .437 & .168 & 2.604 & .009 & Accepted \\
\hline Job autonomy $\rightarrow$ Intention to stay & .718 & .307 & 2.337 & .019 & Accepted \\
\hline $\begin{array}{l}\text { Supervisor support } \rightarrow \text { Intention to } \\
\text { stay }\end{array}$ & -.129 & .253 & -.512 & .609 & Rejected \\
\hline
\end{tabular}

a. The results of the $\mathrm{H}_{1}$ test show a $p$ of 0.854 . It does not meet the criteria of $<0.05$ and the C.R is 0.183 which does not meet the criteria since it is $<1.96$. Thus, $H_{1}$ is rejected. Job autonomy has no significant effect on psychological empowerment of 0.036 .

b. The results of the $\mathrm{H}_{2}$ test show a $p$ of $* * *$. This meets the criteria of $<0.05$ and a C.R of 3,978 which has met the criteria for $>1.96$. Thus, $\mathrm{H}_{2}$ is accepted. It can be concluded that in the second hypothesis, there is strong empirical evidence to reject the null hypothesis $\left(\mathrm{H}_{0}\right)$. Therefore, supervisor support has a positive and significant effect on psychological empowerment of 0.775 .

c. The results of the $\mathrm{H}_{3}$ test show a $p$ of 0.009 . This has met the criteria of $<0.05$ and a C.R of 2.604 which has met the criteria for $>1.96$. Thus, $\mathrm{H}_{3}$ is accepted. It can be concluded that in the third hypothesis, there is strong empirical evidence to reject the null hypothesis $\left(\mathrm{H}_{0}\right)$. Therefore, psychological empowerment has a positive and significant effect on the intention to stay at 0.460

d. The results of the $\mathrm{H}_{4}$ test show a $p$ of 0.019 . This has met the criteria of $<0.05$ and a C.R of 2.337 which has met the criteria for $>1.96$. Thus, $\mathrm{H}_{4}$ is accepted. It can be concluded that in the fourth hypothesis, there is strong empirical evidence to reject the null hypothesis $\left(\mathrm{H}_{0}\right)$. So, job autonomy has a positive and significant effect on the intention to remain significant at 0.527 .

e. The results of the $\mathrm{H}_{5}$ shows a $p$ of 0.609 . This does not meet the criteria of $<0.05$ and a C.R of -0.512 which does not meet the criteria because it is $>1.96$. Thus, $\mathrm{H}_{5}$ is rejected. Thus, it can be concluded that in hypothesis five, there is strong empirical evidence to accept the null hypothesis $\left(\mathrm{H}_{0}\right)$.

Table 10. Summary of the Results of Research Hypothesis 


\begin{tabular}{|c|c|c|}
\hline No & Hypothesis & Description \\
\hline 1 & $\begin{array}{l}\text { The higher level of job autonomy of the nurse, the more } \\
\text { psychological empowerment felt by the nurse }\end{array}$ & Rejected \\
\hline 2 & $\begin{array}{l}\text { The more the supervisor support, the more the psychological } \\
\text { empowerment }\end{array}$ & Accepted \\
\hline 3 & $\begin{array}{l}\text { The more the psychological empowerment, the more the } \\
\text { intention to stay }\end{array}$ & Accepted \\
\hline 4 & The higher level of job autonomy, the more the intention to stay & Accepted \\
\hline 5 & The more the supervisor support, the more the intention to stay & Rejected \\
\hline
\end{tabular}

\section{DISCUSSION}

The results of this study revealed that job autonomy has no significant relationship with psychological empowerment. This study is in line with Akbar et al., (2019) who explains that psychological empowerment shows the role of mediator for job autonomy although it is not significant. Conceptually, empowerment is all efforts to provide autonomy, trust the subordinates, and encourage employees to be creative in order to complete their work well. However, when a nurse has the authority/freedom to do their job, but on the other hand does not feel happy or even comfortable with the job, the nurse indirectly cannot feel psychological well-being.

This study measures that supervisor support has a positive and significant effect on psychological empowerment. Supervisor support given to employees can significantly improve employee psychological well-being. In this case, the supervisor plays an important role in meeting the needs of employees, one way is by empowering them through work-life balance. Supervisor support and psychological empowerment are very important in fulfilling work-life balance. Therefore, the quality of the relationship between subordinates and supervisors greatly affects the potential for job burnout (Yang et al., 2016). Wulandari (2020) revealed that support from supervisors is very important in helping employees to achieve job satisfaction and to prevent depression.

Psychological empowerment has a positive and significant effect on the intention to stay. This means that an employee who feels that their job will automatically create prosperity at work. Thus, it is possible that the employee be loyal to the organization. This study is in line with Hunjra (2011) that empowerment can increase responsibility and motivation at work, increase satisfaction, service quality, loyalty, and productivity that reduce turnover. Nimitha et all., (2018) added that there is psychological empowerment in an organization in creating positive emotions in employees. With a higher level of well-being in the workplace, it will be reflected in a better intention to stay with the organization. 
In addition, job autonomy also has a positive and significant influence on the intention to remain. This shows that employees who already have authority in their work and feel happy with their work can increase the employee's intention to stay. This study is in line with the results of the study of Sheemun et all., (2013) that considers that work autonomy as freedom and independence can increase interest in settling in the workplace. In addition, the research of Tang et al., (2016) states that autonomy serves as an incentive for employees who can increase the intention to stay by showing a high level of engagement in work.

On the other hand, this study shows something different from usual. This is because supervisor support has no significant effect on the intention to stay. In Wulandari's research, (2020) there are other factors that can affect the intention to stay. One of the most dominant variables is compensation or other benefits. When an employee already has support from supervisors, but on the other hand is faced with financial problems with a low salary, it will be possible that the employee will leave the job. This research is in line with the research of Shalihah \& Azzuhri (2018) that supervisor support can increase job satisfaction that has no significant effect on the intention to stay.

\section{CONCLUSION AND SUGGESTION}

Empirically, the concept developed in this study inspires several strategies that could be a solution in increasing the intention to stay. One of the best strategies to increase the intention to stay is influenced by the psychological empowerment they have, where the psychological empowerment of the nurse is assisted by the support from the supervisor. Based on the strategy revealed in this study, the increase in the intention to stay is driven by psychological empowerment, in which nurses feel support from direct superiors, helped in work, taken care of, and comfortable at work. Supervisor support is expected to increase meaningfulness and openness in work, increase employee competence and self-confidence. It is believed that this causes employees to stay in the organization.

The sample in this study were nurses from the Sragen Regency. The results in this study showed that job autonomy has no effect on psychological empowerment. This study also revealed that supervisor support has no effect on the intention to stay. They contradict the research hypothesis. Thus, for further purposes, it is necessary to consider developing the concept of employee intention to stay by using different variables from this study.

\section{REFERENCES}

Aboobaker, N., Edward, M., \& K.A., Z. (2019). Workplace spirituality, employee wellbeing and intention to stay: A multi-group analysis of teachers' career choice. International Journal of 
Educational Management, 33(1), 28-44. https://doi.org/10.1108/JARHE-07-2018-0160

Adame, C., Caplliure, E. M., \& Miquel, M. J. (2016). Work-life balance and firms: A matter of women? Journal of Business Research, 69(4), 1379-1383. https://doi.org/10.1016/j.jbusres.2015.10.111

Akbar, I. B., Hasanati, N., \& Shohib, M. (2019). Pengaruh Otonomi Kerja terhadap Turnover Intention melalui Mediator Pemberdayaan Psikologis pada Karyawan Pertelevisian Cognicia Cognicia. Cognicia, 7(2), 160-174.

Amalia, D. T., \& Handoyo, S. (2018). Peran Psychological Empowerment dalam Hubungan antara Empowering Leadership. Jurnal Psikologi Teori Dan Terapan 2018, 9(77), 77-90.

Baloyi, S., Waveren, C. C. van, \& Chan, K.-Y. (2014). The Role of Supervisor Support in Predicting Employee Job Satisfaction From Their Perception of the Performance Management System : a Test of Competing Models in Engineering Environments. South African Journal of Industrial Engineering, 25(1), 85-95.

Bester, J., Stander, M. W., \& Zyl, L. E. Van. (2012). Leadership empowering behaviour , psychological empowerment, organisational citizenship behaviours and turnover intention in a manufacturing division. Sa Journal of Industrial Psychology, 44(1), 1-14. https://doi.org/10.4102/sajip.v41i1.1215

Chiang, Y. M., \& Chang, Y. (2012). Stress, depression, and intention to leave among nurses in different medical units: Implications for healthcare management/nursing practice. Health Policy, 108(2-3), 149-157. https://doi.org/10.1016/j.healthpol.2012.08.027

Cintantya, D., \& Nurtjahjanti, H. (2018). Hubungan Antara Work-Life Balance Dengan Subjective Well-Being Pada Sopir Taksi PT. Express Transindo Utama Tbk Di Jakarta. Empati, 7(1), 339-344.

Dewettinck, K., \& Van Ameijde, M. (2011). Linking leadership empowerment behaviour to employee attitudes and behavioural intentions: Testing the mediating role of psychological empowerment. Personnel Review, 40(3), 284-305. https://doi.org/10.1108/00483481111118621

Dian Maulida, A. R. S. U. (2017). Pengaruh Modal Psikologis dan Totalitas Kerja terhadap Kesejahteraan Subjektif. Psikohumaniora Jurnal Penelitian Psikologi, 2, No 2, 107-124.

Doble, N., \& Supriya, M. (2010). Gender differences in the perception of work-life balance. Management, 5, 331-342.

Ferdinand, A. (2014). Metode Penelitian Manajemen. Pedoman Penelitian untuk Penulisan Skripsi, Tesis dan Disertasi Ilmu Manajemen (5th ed.). Undip Press.

Ghosh, P., Satyawadi, R., Joshi, J. P., \& Shadman, M. (2013). Who stays with you? Factors predicting employees' intention to stay. International Journal of Organizational Analysis, 21(3), 288-312. https://doi.org/10.1108/IJOA-Sep-2011-0511

Greenhaus, J. H., Collins, K. M., \& Shaw, J. D. (2003). The relation between work-family balance and quality of life. Journal of Vocational Behavior, 63(3), 510-531. https://doi.org/10.1016/S0001-8791(02)00042-8 
Hair, J. F., Anderson, R. E., Babin, B. J., \& Black, W. C. (2010). Multivariate data analysis: A global perspective (Vol. 7). Pearson Upper Saddle River, NJ.

Handayani, A., Desi Maulia, M. A., Dian, P., \& M, N. A. N. (2018). Pengaruh Otonomi Kerja Terhadap Keseimbangan Kerja-Keluarga Dengan Komitmen Peran. Seurune, Jurnal Psikologi Unsyiah, 1(1), 53-73.

Hunjra, A., Ul Haq, N., Akbar, S., \& Yousaf, M. (2011). Impact of Employee Empowerment on Job Satisfaction: An Empirical Analysis of Pakistani Service Industry. Interdisciplinary Journal of Contemporary Research in Business, 2(11), 680.

Iswardhani, I., Brasit, N., \& Mardina, R. (2019). Pengaruh Work-Life Balance dan Burnout terhadap Kepuasan Kerja Karyawan The Effect of Work-Life Balance and Burnout on Employee Job Satisfaction. Hasanuddin Journal of Business Strategy (HJBS), 1 No 2, 1-13.

Leiter, M. P., \& Maslach, C. (2003). Areas of Worklife: a Structured Approach To Organizational Predictors of Job Burnout. Research in Occupational Stress and Well Being, 3, 91-134. https://doi.org/10.1016/S1479-3555(03)03003-8

Lin, J. T. P., \& Ping, N. C. L. (2016). Perceived Job Autonomy and Employee Engagement as Predictors of Organizational Commitment. Undergraduate Journal of Psychology of Psychology, 29(1), 1-16.

Liu, D., Wang, L., Zhang, S., \& Lee, T. W. (2011). The Effects of Autonomy and Empowerment on Employee Turnover: Test of a Multilevel Model in Teams. Journal of Applied Psychology, 96(6), 1305-1316. https://doi.org/10.1037/a0024518

Liu, J., \& Liu, Y. (2016). Perceived organizational support and intention to remain: The mediating roles of career success and. International Journal of Nursing Practice, 2(2), 205-214. https://doi.org/10.1111/ijn.12416

Nesheim, T., Olsen, K. M., \& Sandvik, A. M. (2017). Never walk alone: achieving work performance through networking ability and autonomy. Employee Relations, 39(2), 240-253. https://doi.org/10.1108/ER-09-2016-0185

Nursanti, T. D., \& Anissa, A. D. (2014). Pengaruh Dukungan Supervisor dan Pemberdayaan Terhadap Organizational Citizenship Behavior. Binus Business Review, 5(1), 158. https://doi.org/10.21512/bbr.v5i1.1205

Presbitero, A., \& Teng-calleja, M. (2019). Employee Intention to Stay in an Organization: Examining the Role of Calling and Perceived Supervisor Support Through the Theoretical Lens of Work as Calling. Journal of Career Assessment, 28(2), 302-336. https://doi.org/10.1177/1069072719858389

Raffi, J., Trivedi, M. K., White, L., \& Murase, J. E. (2020). Work-life balance among female dermatologists. International Journal of Women's Dermatology, 6(1), 13-19. https://doi.org/10.1016/j.ijwd.2019.07.001

Ramdhani, G. F., \& Ratnasawitri, D. (2017). Hubungan Antara Dukungan Organisasi Dengan Keterikatan Kerja Pada Karyawan PT. X di Bogor. Jurnal Empati, 6(1), 199-205.

Rehman, S., \& Roomi, M. A. (2012). Gender and work-life balance: A phenomenological study of 
women entrepreneurs in Pakistan. Journal of Small Business and Enterprise Development, 19(2), 209-228. https://doi.org/10.1108/14626001211223865

Rostiana, V. W. P. (2018). Peran Keadilan Organisasi, Karakteristik Pekerjaan dan Pemberdayaan Psikologis Terhadap Keinginan Untuk Menetap (Intention To Stay). Seurune, Jurnal Psikologi Unsyiah, 1(1), 53-73.

Shalihah, M., \& Azzuhri, M. (2018). Pengaruh Komitmen Organisasional dan Kepuasan Kerja terhadap Intention to Stay Relawan di Organisasi Non-Profit ( Studi pada TurunTangan Malang ). Jurnal Ilmian Ekonomi Bisnis, 6(2), 1-15.

Sheemun, Y., Suhaimi, M. N., Abdullah, S. S., \& Rahman, S. A. (2013). Employee Engagement: A Study from the Private Sector in Malaysia. 3(1), 43-48. https://doi.org/10.5923/j.hrmr.20130301.09

Smithikrai, C., \& Phetkham, T. (2019). How leader-follower relations influence nurses' intention to stay: An investigation in a Thai sample. Journal of Social Sciences Research, 5(1), 183-189. https://doi.org/10.32861/jssr.51.183.189

Srimindarti, C., Oktaviani, R. M., \& Hardiningsih, P. (2017). Antecedents of Job Satisfaction and the Influence on Turnover Intention. Jurnal Dinamika Manajemen, 8(2), 177=187.

Suifan, T. S., Abdallah, A. B., \& Diab, H. (2016). The influence of work life balance on turnover intention in private hospitals: The mediating role of work life conflict. European Journal of Business and Management, 8(20), 126-139.

Tourangeau, A., Saari, M. E., Patterson, E., \& Ferron, E. M. (2014). Work, work environments and other factors influencing nurse faculty intention to remain employed: A cross-sectional study. Nurse Education Today, 34, 940-947. https://doi.org/10.1016/j.nedt.2013.05.008

Wulandari, F. (2020). The Effects of Family Issues and Supervisor Support on Work Satisfaction and Work Innovation: A Driver Intention to Remain? Jurnal Manajemen Bisnis, 11(1). https://doi.org/10.18196/mb.11186

Yang, T., Shen, Y., Zhu, M., Liu, Y., Deng, J., \& Chen, Q. (2016). Effects of co-worker and supervisor support on job stress and presenteeism in an aging workforce: A Structural Equation Modelling approach. International Journal of Envirinmental Research and Public Health, 13(72), 1-15. https://doi.org/10.3390/ijerph13010072 